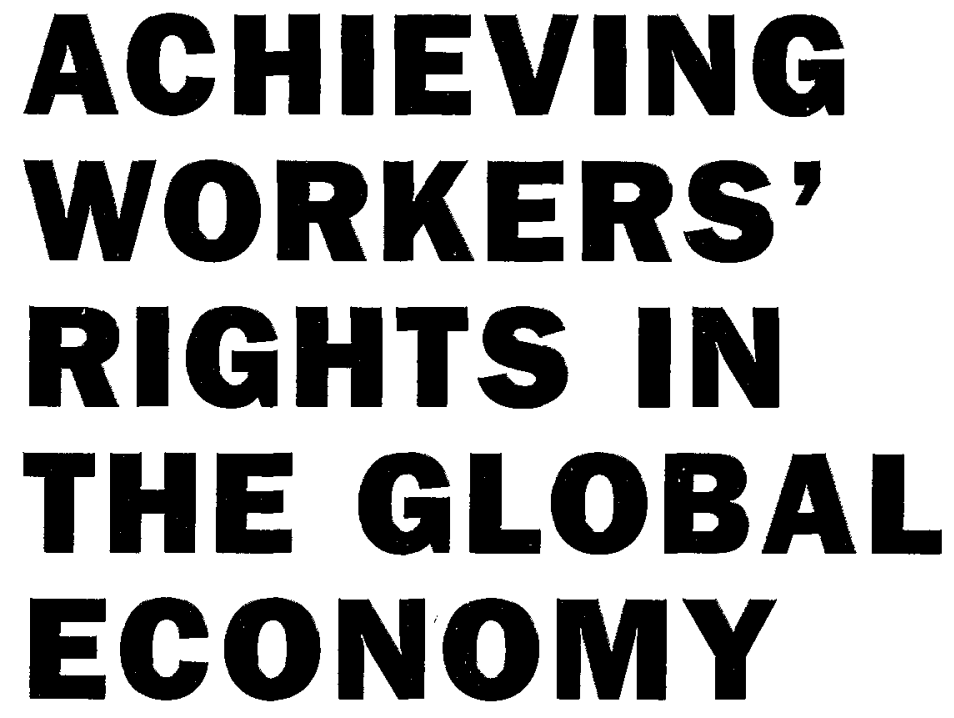

Edited by Richard P. Appelbaum and Nelson Lichtenstein

ILR PRESS, AN IMPRINT OF CORNELL UNIVERSITY PRESS ITHACA AND LONDON 


\section{Copyright $\odot 2016$ by Cornell University}

All rights reserved. Except for brief quotations in a review, this book, or parts thereof, must not be reproduced in any form without permission in writing from the publisher. For information, address Cornell University Press, Sage House, 512 East State Street, Ithaca, New York 14850.

First published 2016 by Cornell University Press

First printing, Cornell Paperbacks, 2016

Printed in the United States of America

Library of Congress Cataloging-in-Publication Data

Names: Appelbaum, Richard P., editor. | Lichtenstein, Nelson, editor.

Title: Achieving workers' rights in the global economy / edited by Richard P. Appelbaum and Nelson Lichtenstein.

Description: Ithaca ; London : ILR Press, an imprint of Cornell University

Press, 2016. | Includes bibliographical references and index.

Identifiers: LCCN 2015048042

ISBN 9781501700033 (cloth : alk. paper)

ISBN 9781501700040 (pbk. : alk. paper)

Subjects: LCSH: Employee rights. | Labor and globalization.

Classification: LCC HD6971.8 .A24 2016 | DDC 331.01/1—dc23

LC record available at http://lccn.loc.gov/2015048042

Cornell University Press strives to use environmentally responsible suppliers and materials to the fullest extent possible in the publishing of its books. Such materials include vegetable-based, low-VOC inks and acid-free papers that are recycled, totally chlorine-free, or partly composed of nonwood fibers. For further information, visit our website at www.cornellpress.cornell.edu.

Cloth printing

Paperback printing

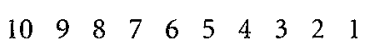

$\begin{array}{llllllllll}10 & 9 & 8 & 7 & 6 & 5 & 4 & 3 & 2 & 1\end{array}$ 
Introduction: Achieving Workers' Rights in the Global Economy

Richard P. Appelbaum and Nelson Lichtenstein

\section{Part I SELF-governANCE: THE CHALLENGES AND} LIMITATIONS OF CORPORATE SOCIAL RESPONSIBILITY

1. Outsourcing Horror: Why Apparel Workers Are Still Dying, One Hundred Years after Triangle Shirtwaist Scott Nova and Chris Wegemer

2. From Public Regulation to Private Enforcement: How CSR Became Managerial Orthodoxy Richard P. Appelbaum

3. Corporate Social Responsibility: Moving from Checklist Monitoring to Contractual Obligation? Jill Esbenshade

4. The Twilight of CSR: Life and Death Illuminated by Fire Robert J. S. Ross

\section{Part II GOVERNANCE OF GLOBAL PRODUCTION NETWORKS}

5. The Demise of Tripartite Governance and the Rise of the Corporate Social Responsibility Regime Nelson Lichtenstein

6. Deepening Compliance?: Potential for Multistakeholder Communication in Monitoring Labor Standards in the Value Chains of Brazil's Apparel Industry Anne Caroline Posthuma and Renato Bignami

7. Law and the Global Sweatshop Problem Brishen Rogers

8. Assessing the Risks of Participation in Global Value Chains Gary Gereffi and Xubei Luo 
9. Apple, Foxconn, and China's New Working Class Jenny Chan, Ngai Pun, and Mark Selden

10. Labor Transformation in China: Voices from the Frontlines Katie Quan

11. CSR and Trade Union Elections at Foreign-Owned Chinese Factories

Anita Chan

\section{Part IV A WAY FORWARD?}

12. The Sustainable Apparel Coalition and Higg Index: A New Approach for the Apparel and Footwear Industry Jason Kibbey

13. Learning from the Past: The Relevance of Twentieth-Century New York Jobbers' Agreements for Twenty-First-Century Global Supply Chains Mark Anner, Jennifer Bair, and Jeremy Blasi

14. Workers of the World Unite!: The Strategy of the International Union League for Brand Responsibility Jeff Hermanson

Notes

References

Contributors 
We wish to acknowledge the people and organizations who helped make this book possible and who provided invaluable assistance along the way: the MacArthur Foundation, whose endowed chairs supported our work on workers' rights around the globe; the Rockefeller Foundation's Bellagio Center, for hosting the conference that resulted in this book, as well as our month-long residencies, where we were able to do collaborative writing on workers' rights; Gaye Tuchman, who from the beginning realized the importance of a book publication resulting from our conference; Shirley (Xueying) Han, who helped to organize our conference and managed the "supply chain" of book contributors; Fran Benson, editorial director of ILR Press at Cornell University Press; Karen M. Laun, our patient production editor at CUP; Mary Petrusewicz, our copyeditor; and Jim O'Brien, our indexer. 


\title{
ACHIEVING WORKERS' RIGHTS IN THE GLOBAL ECONOMY
}

\author{
Richard P. Appelbaum and Nelson Lichtenstein
}

The world was shocked in April 2013 when more than eleven hundred garment workers lost their lives in the collapse of the Rana Plaza factory complex in Dhaka. It was the worst industrial tragedy in the two-hundred-year history of mass apparel manufacture. This was an accident just waiting to happen, and not merely because of the corruption and exploitation of workers so common among the four million garment workers in Bangladesh. The real cause of the disaster, as well as the low wages, poor working conditions, and voicelessness endemic to the vast majority of workers who labor in the export industries of the global South, arises out of the very nature of world trade and production.

Today retail-dominated supply chains, of which those commanded by executives at Walmart, Apple, Nike, Zara, and H\&M are the most prominent, generate at least half of all world trade and "employ" hundreds of millions of workers in thousands of contract manufacturers from Shenzhen and Shanghai to Sao Paulo and San Pedro Sula. Given their enormous power to squeeze prices and wages, these North Atlantic brands and retailers today occupy the commanding heights of world capitalism.

The essays collected in Achieving Workers' Rights in the Global Economy offer an incisive analysis of this pernicious system alongside proposals for its radical reform. Its contributors, many of whom have years of experience studying or working with major companies, nongovernmental organizations, international regulatory bodies, and trade unions on more than four continents, explain 
why so many high-profile corporate social responsibility programs have failed, why real wages have declined in much of the garment-manufacturing sector, and why unions and other forms of worker self-organization have had such difficulty establishing themselves in China, South Asia, and Central America. The concluding chapters call for cross-border regulation, worker self-empowerment, and brand and retailer legal responsibility for the wages, working conditions, and safety of all those who labor in their contract factories.

\section{The Changing Nature of Production}

Today's globalization differs from that of even a few decades past because of the big-box retail chains-the big buyers that have often displaced the large manufacturing firms that once reigned supreme as the central pillars and most consequential entities in the capitalist economy during most of the twentieth century. The Walmarts, Home Depots, and Carrefours sit atop global supply chains, along with brands such as Apple and Nike. They make the markets, set the prices, and determine the worldwide distribution of labor for that gigantic stream of commodities that flows across their counters (Lichtenstein 2009). The loss of US goods-producing manufacturing firms to low-wage countries has entailed not just cheap labor competition from abroad but also a historic shift in power within the structures of world capitalism from manufacturing to a retail sector that controls the supply chains spread around the planet.

These buyer-driven commodity chains play a pivotal role in setting up the decentralized production networks that today stand at the heart of transnational capitalism. Producer-driven supply chains, characteristic of capitalintensive industries such as automobiles, aircraft, computers, semiconductors, and heavy machinery, still exist, but their relative importance has declined since the mid-twentieth century, when multinational manufacturers played the dominant role in coordinating worldwide production networks. In contrast, the retailers and marketers who stand at the apex of the buyer-driven global commodity chains of our day are best understood as "branded marketers" who do not actually make their own products, but rather design and advertise them, thus creating a market based on product image and recognition. Actual manufacturing takes place in a worldwide set of independently owned contract factories that purchase the raw materials, recruit and pay the workers, and oversee all aspects of the production process. This system is most advanced within the world of light manufacturing, especially apparel, shoes, and consumer electronics, but the output of more complex, capital-intensive products, including high-value aviation and computer parts as well as call-center services 
contracted to phone companies and airlines, is rapidly becoming a link in these global supply chains.

The result of this shift has been a parallel transformation in the nature of economic governance. In the era after the Great War, social democrats on both sides of the Atlantic sought to institutionalize a "tripartite" structure in which the state, the corporations, and the unions negotiated with one another in order to reach a set of social and economic outcomes that some latter-day observers would denominate a "social compact." Although such a corporatist settlement seemed within reach during the height of the Second World War and the most fraught Cold War years that followed, in the United States it never achieved the legitimacy that would for many decades characterize class politics in Austria, West Germany, and the Nordic countries (Moody 1988; Swenson 1989; Jacoby 1997; Swenson 2002; Phillips-Fein 2010; Lichtenstein 2013). Nevertheless, it remained an aspiration, encoded and advanced most consistently by the International Labour Organization (ILO), where a "tripartite" structure was embedded within the very DNA of organizational decision making and implementation.

Today, of course, such twentieth-century industrial tripartism is in decay. In the United States collective bargaining as a mechanism for setting labor standards no longer has an effective state patron, and in Europe unionism is also in decline and state patronage is on the wane. In East Asia, the new workshop of the world, authoritarian governments of a Stalinist or militarist character have given way to hypercapitalist ruling coalitions that are just as determined to suppress working-class claims to autonomous organization and power sharing. Into this vacuum-both of industrial governance and the ideology essential to sustain it-have stepped the giant corporations of our time who have deployed the framework known as corporate social responsibility (CSR) as a new kind of tripartism in which negotiations now take place between those brands and retailers at the top of the supply chain, their contract factories in Asia and Central America, and a set of nongovernmental organizations (NGOs) whose role it is to substitute themselves for both an indifferent or weak state and the workers themselves, whose level of political and economic organization remains anemic.

This arrangement effectively makes corporations responsible for monitoring themselves, and in turn has given rise to a global compliance industry. Whereas Jill Esbenshade famously argued that in a world dominated by global supply chains a new "triangle of power" now exists, "with employers, contractors, and the government forming its points" (Esbenshade 2004a, 33; see also chapter 3), we take the argument one step further to argue that government itself is largely absent: the three points on the triangle are now the brands, their contract factories, and the set of largely Western NGOs that prod the corporations to improve 
labor standards and monitor the firms hired by the brands to inspect their factories and report back (to the brands) their findings.

\section{Self-Regulation in Global Industries}

In response to these developments, and in the United States and Europe a growing anti-sweatshop movement (see chapters 2 and 14), ${ }^{1}$ businesses have since the late 1990s emphasized the importance of corporate social responsibility, sustainability, fair trade, and the "triple bottom line" (profits, equitable business practices, environmental sustainability). Leading corporations such as Nike and Walmart have adopted codes of conduct that are intended to require their suppliers to behave according to ethical business practices as well as signal their customers that such practices are reflected in their products. The growing interest in equitable business practices is reflected in a large number of organizations and institutions that have been created since the 1990s, as well as the theoretical and empirical attention that has been given to these issues in the literature and in business school curricula (Tickle 2009). A small sampling of organizations and institutions would include Businesses for Social Responsibility (now simply BSR), the Fair Labor Association (FLA), the Sustainable Apparel Coalition, Green America, and the United Nations Global Compact. Among business and management schools that emphasize corporate social responsibility issues, the top ten would include the Ross Business School, University of Michigan; Yale School of Management; Stanford Graduate School of Business; Mendoza Business College, Notre Dame; Haas Business School, University of California at Berkeley; Stern Business School, NYU; Columbia University Business School; Darden Business School, University of Virginia; Johnson Graduate School of Management, Cornell; and the George Washington University School of Business.

Businesses have been especially keen to emphasize sustainable environmental practices. This most likely stems from several sources: genuine ethical concern, the recognition that ecologically sustainable practices can open up new market opportunities, concern that embarrassing revelations involving pollution or sweatshop production might hurt brand image, and the desire to cut costs through greater efficiency (for example, when green technologies reduce fossil fuel consumption). The policing of supply chains-at least on the environmental side- has come to be regarded as legitimate by a growing segment of the business community. In the most widely discussed example (because of its enormous potential impact), Walmart in 2009 notified its approximately one hundred thousand global suppliers that they would henceforth be required to estimate and report their carbon footprint. This would be put into an index that 
would then be reported on the product's price tag, enabling consumers to take into account its ecological impact. Walmart's efforts are not only good PR but they are also good for Walmart's bottom line, since energy costs across the company's global supply chains are being reduced as a result. As the world's largest retailer, Walmart's sustainability program will certainly have a large environmental impact and provide a template competitors will feel pressure to emulate. Although businesses that have embraced environmentally sustainable practices have been accused of "greenwashing"-engaging in public-relations efforts that entail few actual changes in practices - there is some evidence that at least in this area, business's economic and social objectives can coincide: ecologically sustainable products now command a large market and cost-cutting based on any criteria is essential to efficient supply-chain management. ${ }^{2}$

If some businesses have clearly taken preliminary steps toward developing environmentally sustainable products, progress is far more problematic when it comes to labor issues involving wages, hours, health and safety, and the right to freedom of association. Corporations that adopt fair labor standards typically do so by deploying codes of conduct that apply to their supply chains, while avoiding the transparency and independent monitoring of actual results that would permit effective evaluation of their programs. We term this practice "bluewashing," that is, a mere rhetorical and reputational commitment toward the improvement of labor standards.

NGOs have become highly active in this area-some working with corporations to provide a variety of monitoring services for purposes of selfenforcement, others as independent monitors (or, more often, industry watchdogs) that are highly critical of the corporate ability to self-regulate. Examples of the former include the Global Social Compliance Program, Veritas, and PwC, a separate legal entity of PriceWaterhouseCoopers International. Examples of the latter are numerous: the Worker Rights Consortium (WRC), the Fair Labor Association (FLA), Maquila Solidarity Network, and the International Labor Rights Forum. ${ }^{3}$

Finally, some transnational governmental institutions seek to raise labor standards, but their effectiveness remains unclear. The UN Global Compact, enacted in the late 1990s, represents an essentially aspirational manifesto designed to facilitate business self-regulation on an international scale (see chapter 2). More substantial is the work of the ILO, which periodically establishes new international labor standards, normally embodied in a convention and adopted by two or more countries. But ILO standards lack effective enforcement mechanisms and so are seldom honored outside of the rich social democracies of Europe. Indeed, the United States remains an outlier, having adopted only two of the ILO's eight core labor-standard conventions. China has adopted none. Moreover, 
the ILO is committed to the old tripartite schema involving capital, labor, and the state, a framework, as we have seen, that has little bearing in a world where the key actors are brands, suppliers, and the organizations that brands hire to monitor their supply chains. Labor and the state are noticeably absent from this new arrangement. (The role of the ILO is discussed more extensively in chapters 2 , 5, and 6.)

\section{The Growth of Big Suppliers: A New Opportunity for Activism?}

Whereas the growing importance of big buyers-major brands and retailers-in supply chains has been well documented, less appreciated is the parallel rise of giant transnational contractors, based primarily in Hong Kong, Taiwan, South Korea, and China. They operate factories primarily in East Asia (China, Vietnam, Malaysia, Singapore, and Indonesia), Mexico, and Central America, although they are beginning to appear in Africa and Latin America as well. Such "big suppliers" are themselves market makers for their own contract suppliers, exerting increasing control over key aspects of the production supply chain. ${ }^{4}$

In the textile and apparel industries, the consolidation of production, both at the factory and country level, is highly pronounced, having accelerated after the demise of the thirty-year Multi-Fiber Arrangement (MFA). Under the MFA's quota system, clothing production had been dispersed to some 140 countries, but when the arrangement was phased out in 2005 the consolidation of clothing production into a few larger companies and a small number of supplying countries accelerated because of the economies of scale that could be achieved and because some nations, such as China and Vietnam, had the infrastructure to efficiently sustain high levels of export production.

Examples of giant East Asia-based contractors abound. In the footwear industry, the firm Yue Yuen boasts of being "the largest branded athletic and casual footwear manufacturer in the world" (Pou Chen 2015). The company's sprawling complexes (resembling small cities) produce for Nike, adidas, Reebok, Asics, New Balance, Puma, Timberland, and Rockport, whose production occurs in side-byside factory buildings. Yue Yuen was founded by the Tsai family in Hong Kong in 1988. They also control the Taiwanese firm Pou Chen, the largest shareholder in Yue Yuen, which has acquired Pou Chen's interest in nearly seventy companies providing raw materials, production equipment, and shoe components, along with a number of companies engaged in sportswear and casual apparel manufacturing. In the textile and apparel industries, the Taiwanese multinational Nien Hsing Textile Co. Ltd supplies such customers as The Gap, Kohl's, Levi Strauss, 
Liz \& Co., Target, and Oshkosh B'Gosh. It has denim mills or factories in Taiwan, Mexico, Nicaragua, Vietnam, Cambodia, and Lesotho. Yupoong Inc., a Korean multinational that has become one of the world's largest cap manufacturers, has supplied its "Flexfit" caps to markets around the world-including (in the United States), the NBA, MLB, NFL, NHL, and NCAA. And when it comes to assembling consumer electronics, the Taiwanese company Foxconn is by far the largest: grossing nearly $\$ 65$ billion in sales, Foxconn is the single largest private employer in China, with 1.4 million workers in Asia, Europe, and Latin America (see chapter 9).

This consolidation of production results in an industry-driven designated supplier program in which major brands and retailers increasingly source their production from a smaller number of large multinational manufacturers. As we shall see in the cases of Nike and Apple, this creates new opportunities for public disclosure and concerted pressure to ameliorate conditions. It also begins to reproduce the social and organizational environment that existed during the heyday of union organizing in the twentieth century: large factories that are vulnerable to mass work stoppages and a supply chain that is vulnerable to such worker pressure at a variety of points from Asian ports to US trucking and distribution sites. Although these export manufacturers remain independently owned contract factories, to the extent that they account for a significant portion of their clients' products, worker or consumer action directed against the factories can have a strong impact on brand reputation and retailers that sell such well-known consumer goods.

\section{Recent Developments May Hold Some Promise}

We argue that as aspirational statements, corporate codes of conduct set a public standard to which firms can be held accountable. Even when imperfectly asserted and enforced, such an enunciation of a corporate standard opens the door to the kind of "naming and shaming" that has become an NGO specialty. Recent victories by the anti-sweatshop movement have shown that public pressure on leading brands can result in significant changes in their behavior. Although generally restricted to the university apparel sector, these victories have sent signals throughout the industry. Though very few brands have made changes that go beyond their licensed university products, well-publicized campaigns against brands such as Nike and Russell Athletic contribute to a climate of concern that is reflected in the proliferation of codes and brand alliances that at least pay lip service to enforcement (see chapter 14).

Nike provides an excellent case study. When United Students Against Sweatshops, and others who favored development of collegiate codes of conduct for companies that sold their product in university bookstores, began a boy- 
cott campaign against Nike in the early 1990 s, the company claimed that more transparency-involving contract manufacturers and working conditionswould destroy their business, a claim still made by most brands and retailers today. But student activism and consumer pressure forced Nike to develop a wellformulated code of conduct and then regularly issue CSR reports. The company began to work cooperatively with the WRC and FLA and it provides a public website that is said to include all of its contractors and subcontractors. ${ }^{5}$ Most important, Nike has moved much of its footwear production into its giant Yue Yuen factory complexes in Dongguan. Of course, without either effective unions or much state regulation, problems clearly persist in Nike's supply chain, as the authors of chapters 2, 3, and 14 discuss.

Apple provides another instructive case study. Apple is reportedly the world's most admired company; in the second decade of the twenty-first century it also became the world's most valuable company, at least as measured by stock capitalization. Components for Apple products are sourced all over the world but assembled primarily in Foxconn's Chinese factories. When revelations surfaced, beginning in 2011, about despondent workers committing suicide in Foxconn's Shenzhen factory, enormous public pressure forced Apple to join the FLA, which conducted worker audits on Apple's behalf; Foxconn also raised wages. But as is described in detail in chapter 9 , these victories proved to be more illusory than real: wage and hour violations persist, and Foxconn responded in part by reducing its workforce in Shenzhen and moving production to western provinces, where wages are much lower.

It is a good thing that firms have committed themselves to the maintenance of codes of conduct that address wages and working conditions. But meaningful improvements are unlikely to occur unless retailers and brands are willing to front any higher labor costs associated with code enforcement, since supplier factories will claim (with some justification) that they are already being squeezed. Factory giants like Yue Yuen and Foxconn may be able to absorb some higher costs, but their profitability is unlikely to extend to the smaller suppliers and subcontractors. This is why factory consolidation is such an important development. The mutual reliance of big buyers and big suppliers on one another can create opportunities to apply the sort of leverage, via publicity and even boycotts, that force export manufactures to make improvements to their operations that can affect hundreds of thousands of workers after just one campaign. Such consumer pressure, over time, may help to achieve workers' rights, beginning by creating a market niche for truly labor-friendly products. But this is hardly a long-term solution, since consumer consciousness can be so unreliable and fickle. ${ }^{6}$

Passing (and enforcing) labor-friendly laws in supplier countries may also prove helpful, as is evidenced by Indonesia's rulings that workers at PT Kizone, abruptly 
shut down by its Korean owner, were entitled to legally mandated severance pay (see chapter 14). Even China, long dependent on cheap exports for amassing its mountain of foreign-reserve currencies, enacted a contract labor law in 2008 that guarantees workers some basic rights (Wang et al. 2009). China has also raised worker wages in the coastal provinces where most factory production occurs, and worker militancy has begun to make some inroads into China's state-controlled labor unions (see chapters 9, 10, and 11). Yet these developments reveal some of the problems in state-level action: rising wages and improved working conditions in a single country can lead to capital flight to less labor-friendly (and lower-cost) countries. This is currently the case with China, where low-cost production is now being offshored to Bangladesh, Vietnam, Cambodia, and many African countries.

Enforceable (and enforced) trade treaties involving the leading apparel importing countries could level the playing field, since brands would be required to comply regardless of where they produced their products. Such "social clauses" in trade agreements would, however, likely be challenged as in violation of World Trade Organization (WTO) trade liberalization requirements. In the long run, perhaps, even the WTO might change its charter to incorporate ILO core laborstandard conventions-provisions that then might be enforced by the ILO itself.

All of these efforts can contribute to selective improvements in working conditions, particularly where major brands and their large-scale suppliers are involved. CSR, though limited in crucial ways, should not be dismissed out-of-hand by anti-sweatshop activists: to the extent that it opens the door to previously hidden working conditions in global supply chains, it provides an opportunity for activists to push for that door to open still further.

\section{Organization of This Book}

The four chapters in part 1 provide a detailed look at CSR, examining why it has failed to achieve its professed objectives. In chapter 1, Scott Nova and Chris Wegemer survey the many challenges that must be confronted in achieving workers' rights in global supply chains. Nova, head of the WRC and one of the chief negotiators of the innovative Bangladesh Accord on Fire and Building Safety, graphically chronicles the efforts to achieve a meaningful (and enforceable) solution to the ever-present danger of fires and building collapses among Bangladesh's thousands of garment factories. Drawing on his experience as one of the architects of the 2013 Accord, he documents two principal challenges: remediating the physical dangers Bangladeshi workers encounter daily and overcoming the resistance of brands and retailers to incurring a legal obligation to make the necessary remediation, even if it means covering the costs themselves. The failure 
of voluntary CSR and the need for binding commitments (some form of "joint liability" between the brands/retailers and their contract factories) are themes that will run throughout this book.

In chapter 2, Richard Appelbaum examines the history of the CSR idea, tracing its corporate origins as well as its internationalization in approaches favored by the United Nations. During the early part of the twentieth century, when production was largely national in scope, strong unions in the United States and other industrial nations were able to achieve varying degrees of government regulations that protected workers' rights. These protections reflected a tripartite laborcapital-state system of corporate governance envisioned as early as 1919 with the birth of the ILO. But during the latter part of the twentieth century, as production went global, state regulation gave way to corporate self-regulation-private enforcement of codes of conduct that corporations adopted in the face of embarrassing revelations of labor abuses in overseas contract factories. This approach, taught in business schools, embraced universally by corporations, and reflected in the United Nations Global Compact, has failed to secure workers' rights.

In chapter 3, Jill Espenshade begins with an extensive review of some fifty studies that examine the success, failure, and challenges of codes of conduct and monitoring efforts, looking at the wide variety of practices, the role of worker participation, the importance of independence and transparency, consumer activism, government enforcement, and the relationship between brands/retailers and their suppliers. She argues that although the ultimate solution lies in strong government enforcement, "moving from checklist monitoring to contractual obligation" between brands/retailers and their suppliers can play an important role in enforcing substantive codes of conduct.

In chapter 4 Robert Ross provides research that graphically documents the failure of CSR. He begins with a historical review of the origins and development of CSR before turning to the principal critiques of its weaknesses. He then reviews the history of the many fires and building collapses in Bangladesh, the preferred lowest-cost site for many Western brands and retailers, focusing on case studies of disasters in buildings that had been preceded by favorable CSR audits and monitoring reports. He concludes with an argument for joint liability, introducing a discussion of the so-called jobbers' agreements between manufacturers (known as "jobbers") and union shops in New York City's garment industry during the 1920s and 1930s. The history and relevance of jobbers' agreements as a way forward are also discussed in detail by Mark Anner, Jennifer Bair, and Jeremy Blasi in chapter 13.

The four chapters in part 2 offer different approaches to the governance of global supply chains: greater vertical integration of production, encouraging international labor standards through the ILO, developing private transnational 
law, and upgrading in global supply chains. In chapter 5 , Nelson Lichtenstein begins with a discussion of the degree to which the disaggregation of the vertically integrated corporation, combined with the emergence of an era of "thin" states incapable of regulating their own economies, has rendered the idea of tripartite industrial governance an antique relic of an increasingly distant time. Retail-dominated global supply chains therefore remain virtually unregulated by the nation-states that host their production facilities, while trade unions remain weak throughout the export industries of East Asia. All this has proven a challenge to the ILO even as it tries to accommodate its regulatory mission to the new architecture of corporate power. Lichtenstein therefore examines three ILO initiatives designed to salvage a measure of industrial tripartitism. The ILO itself remains skeptical of the entire CSR project, but has nevertheless established a voluntary corporate "help desk" designed to facilitate CSR initiatives that base their codes and standards on established ILO conventions. The limitations of the ILO approach are revealed in the ILO's Better Factories Cambodia program, an initiative strongly supported in its formative years by the United States.

In chapter 6, Anne Caroline Posthuma and Renato Bignami examine a CSR initiative recently introduced by the Brazilian Association of Apparel Retailers, which they argue offers the potential of bridging two prevalent regulatory gaps in global supply chains: the gap between private-sector audits and public labor inspections and the gap between first- and lower-tier suppliers. Using a globalvalue-chain approach, which examines the possibilities of upgrading into higher value-added production, this chapter argues that despite the many challenges that still exist in Brazil, when strong communication exists between a vigorous public labor inspectorate and the leading association of apparel retailers, it may prove possible to bridge the public/private and first-tier/lower-tier regulatory gaps that commonly exist in the promotion of labor standards in global and national value chains.

In chapter 7, Brishen Rogers examines the challenging relationship between global legal structures and global value chains through which brands operate and shape workers' responses. He shows how workers' organizations are increasingly bypassing national-level collective bargaining laws and procedures, holding brands accountable through private contractual agreements linking brands, suppliers, and workers, as seen in the Bangladesh Accord on Fire and Building Safety. Such agreements, which take the form of contracts that are enforceable through binding arbitration in national courts, may prove to be a way forward (although how they will stand up in national courts remains to be seen). More important, he argues, such contracts empower workers' organizations in creating and enforcing labor law "from below," linking workers across borders directly to brands, a topic that is further discussed in chapter 14 . 
In chapter 8, Gary Gereffi and Xubei Luo employ a global-value-chain framework to show that although in some cases it is possible to "capture the gains" from economic upgrading, this is not always possible. The economic dividends generated by participation in global supply chains do not necessarily translate into good jobs or stable employment. Moreover, the economic upgrading experienced by some export-oriented low-income countries has been associated with a significant deterioration of labor conditions. The authors call on governments to take several steps to improve workers' lives. These include playing a central role in addressing the risks for workers, enforcing regulations that address working conditions, and facilitating human capital development by collaborating with universities and firms to enhance workforce development.

The three chapters of part 3 examine the prospects for workers' rights in China-a country now emerging as the planet's most important manufacturing power with a proletariat numbering in the hundreds of millions. As these chapters show, workers are not quiescent in China but in various ways-always constrained by the state-have been effective in demanding and winning better working conditions and wage improvements.

In chapter 9, Jenny Chan, Pun Ngai, and Mark Selden take an insider's look at what they term China's "new working class" by focusing on the giant Foxconn factories that produce consumer electronics for Apple and many other brands. Based on an examination of reports as well as interviews with workers and managers, they argue that Apple, not Foxconn, reaps the profits from their production relationship, with a resulting downward squeeze on wages and working conditions. Workers have responded: initially with well-publicized suicides of despondent workers in Foxconn's Longhua Shenzhen factory, then with strikes and worker protests at Foxconn factories throughout China. Because China's government sees these direct actions as threatening social stability, it has forced Foxconn and other employers to raise wages, while enacting some limited policies that improve workers' lives.

In chapter 10, Katie Quan takes a hard look at recent labor struggles in southern China, focusing especially on the role of wildcat strikes, which have forced the government, and the government-controlled unions, to provide disputeresolution mechanisms that give workers increasing voice through collective bargaining and election of union leaders. Through a series of case studies and interviews with labor activists, she shows that although these developments have the potential for increasing worker power, the Communist Party-which controls the unions-remains a barrier: wildcat strikes may be tolerated, but formal, openly declared union strikes are not. The chapter concludes with a call for increased dialogue and exchanges with US unions as a way of strengthening China's unions and fostering joint actions. 
In chapter 11, Anita Chan looks at trade union elections throughout China, arguing through a series of case studies that five types of elections are reshaping labor practices there. These five fall into two broad categories: trade union elections initiated by parties other than the workers themselves (by multinationals, by foreign trade unions and NGOs, or by China's government-controlled AllChina Federation of Trade Unions, the ACFTU) and elections initiated by the workers themselves (initiated and organized by workers or initiated by workers but organized by the union). These cases show that there is an emerging awareness on the part of workers of the importance of true democratic labor representation in China, something even the ACFTU now understands. Professor Chan concludes that both categories of labor activism have encountered difficulties. Where workers are passive (the first category), any gains realized can be quickly withdrawn. Where workers are active (the second category), their actions often face repression from company or regional government, resulting in a loss of momentum and few if any permanent gains. Nonetheless, she argues, in the long run, these varied experiences are ones of learning and consciousness formation that may prove invaluable for achieving workers' rights in China.

The three chapters in part 4 draw on past and current labor struggles to chart a way forward. In chapter 12, the Sustainable Apparel Coalition's (SAC) Jason Kibbey offers the apparel and footwear industry's preferred approach: strengthening CSR efforts by statistically measuring the social, labor, and environmental impacts of factory production through the use of the Higg Index. SAC is an industry-wide group of leading apparel and footwear brands, retailers, manufacturers, NGOs, and academic experts working to measure and improve the environmental and social impacts of the apparel and footwear industry. Kibbey briefly describes the history, membership, and aspirations of the SAC before turning to an extended discussion of the Higg Index itself: its origins, function, and the theory of change it embodies.

In chapter 13, Mark Anner, Jennifer Bair, and Jeremy Blasi provide a detailed look at the early jobbers' agreements in the United States, which they argue can serve as a model for achieving some form of joint liability between brands and retailers on the one hand, and their globally dispersed contract factories on the other. Examining the history of the International Ladies' Garment Workers' Union during its mid-twentieth-century heyday, they find that key elements of the original jobbers' agreements are replicable today: direct wage negotiations, stabilization of contracting relationships by registering contractors with the union, and making jobbers directly liable for labor costs beyond wages. The chapter concludes with a discussion of possible approaches to joint liability in today's global supply chains that draw on these lessons: global framework agreements negotiated between international union federations and multinational 
companies or global brands, university codes of conduct and student corporate campaigns, and the Accord on Fire and Building Safety in Bangladesh. They argue that effective domestic laws and international labor standards are, by themselves, insufficient: binding agreements that create joint liability are necessary to achieve meaningful (and enforceable) workers' rights.

In chapter 14, Jeff Hermanson examines current efforts to foster cross-border union solidarity and labor organizing. After first reviewing the history of labor organizing in the garment industry, he turns to current global efforts, including some in which he has been directly involved, discussing their strengths and weaknesses. The emergence of global federations of unions is one promising development. Beginning in 2012, the International Union League for Brand Responsibility has linked a number of national unions together, employing an original strategy: global campaigns against a single brand that target dozens of the brand's contract factories around the world. Although this approach is not without difficulties, Hermanson writes that it has the potential to bring rank-and-file factory workers face to face at the bargaining table with the top executives of some of the most powerful and wealthy corporations in the world. 


\section{Part I}

\section{SELF-GOVERNANCE}

The Challenges and Limitations of Corporate Social Responsibility 


\section{OUTSOURCING HORROR}

\section{Why Apparel Workers Are Still Dying, \\ One Hundred Years after Triangle Shirtwaist}

\section{Scott Nova and Chris Wegemer}

The fire broke out at 5:30 p.m., right after the bell sounded the end of the workday. The building is $\mathbf{1 0}$ stories high. The Triangle Waist Company occupied the top three floors, and that is where the fire started . . . The flames spread very quickly. A stream of fire rose up through the elevators to the uppermost floors. In the blink of an eye, fire appeared in all the windows and tongues of flame climbed higher and higher up the walls, as bunches of terrified working girls stood in astonishment. The fire grew stronger, larger and more horrifying. The workers on the upper floors were already not able to bear the heat and, one after another, began jumping from the eighth, ninth and 10th floors down to the sidewalk where they died.

-The Forverts, March 26, 1911

Survivors have described how a fire tore through a multi-story garment factory just outside Bangladesh's capital, Dhaka, killing more than 100 of their colleagues . . . Muharnmad Shahbul Alam, 26, described flames filling two of the three stairwells of the nine-floor building-where clothes for international brands . . . appear to have been made ... . Rooms full of female workers were cut off as plles of yarn and fabric filling corridors ignited. Reports also suggested fire exits at the site had locks on, which had to be broken in order for staff to escape . . . Witnesses said many workers leapt from upper stories in a bid to escape the flames.

-The Guardian (Burke and Hammadi), November 25, 2012

Time and again when workers speak up with concern about safety risks, they aren't listened to. And in the moment of crisis, when the fire alarm goes off or a building starts to crack, workers' voices not only fall on deaf ears, but they are actively disregarded . . . Change can happen. It is happening. But there's still a long way to go.

-Kalpona Akter, Bangladesh Center for Worker Solidarity, January 23, 2014 
On March 25, 1911, on the top floors of a ten-story building on the corner of Greene Street and Washington Place in lower Manhattan, a fire broke out in a factory operated by the Triangle Shirtwaist Company. As smoke and flames rapidly spread, a lack of fire exits made escape impossible; workers desperately scrambling for egress found only locked doors. Many chose to leap to their deaths rather than succumb to the flames. One hundred and forty-six people, mostly young women in their late teens and early twenties, died in a tragedy that helped catalyze a national movement for workplace reform.

Unfortunately, we don't need a history lesson to contemplate the horror of garment workers falling to their deaths from the high floors of a burning factory. The abusive conditions, poverty wages, and shoddy garment industry safety practices that unions and social reformers decried in 1911 have not disappeared. They have been relocated. Today, leading apparel brands and retailers produce their goods in countries like Bangladesh, now the world's second-largest garment exporter, where from 2005 to 2013 nearly two thousand workers were killed in more than a dozen fires and building collapses. Each of these disasters arose from the same kind of reckless disregard for worker safety that produced the tragedy at Triangle Shirtwaist.

Thanks to decades of legislative reform and union activism, by the 1950s apparel production in the United States came to be defined by decent wages, strong unions, and enforceable safety regulations. However, as communications and transportation technology made overseas production increasing feasible, clothing brands and retailers eventually relocated the manufacturing of garments to countries that offered what the United States no longer did: workers willing to toil for poverty wages and governments willing to turn the other way while factory managers cut costs by ignoring labor standards. It is important to bear in mind that low wages, though important, were never the sole attraction; the savings that can be derived in an environment of lax-to-nonexistent regulation are also substantial.

Unconstrained by regulation, apparel producers in 1911 Manhattan did not waste money on niceties like workplace safety. Neither do their counterparts today in Bangladesh and many other garment-producing countries. Leading Western apparel brands and retailers have thus accomplished a perverse form of time travel: they have re-created 1911 working conditions for millions of twentyfirst-century garment workers.

On no issue has the cost to workers been more obvious, or more tragic, than workplace safety. The garment industry has known for a century how to operate an apparel factory safely, a lesson learned in the wake of the Triangle Shirtwaist fire. Moreover, virtually every exporting country, including Bangladesh, has laws on the books that require proper building design and operation. Yet in Bangla- 
desh, prior to recent reform efforts spurred by the Tazreen Fashions fire (November 2012) and the Rana Plaza building collapse (April 2013), it is highly likely that none of the country's 3,500 garment factories had fire exits or sprinkler systems. Hundreds were structurally unsound. No factories were found to be even close to meeting safety standards (Accord on Fire and Building Safety in Bangladesh 2014). As a result, millions of garment workers risked their lives every day merely by going to work.

This recklessness explains why, despite all of the last century's advances both in the technical understanding of building safety and in the official recognition by governments and corporations of the rights of workers, three of the four worst disasters in the centuries-long history of mechanized garment production have occurred in the three years before 2015.

Only in the wake of the worst of these, the Rana Plaza collapse, which generated weeks of worldwide media coverage highly embarrassing to leading brands and retailers, was it finally possible to persuade some of these corporations to commit to take the action necessary to make garment factories in Bangladesh safe.

In the following, we discuss why preventable mass fatality disasters continue to occur in factories producing the clothing of major Western brands and retailers more than one hundred years after the Triangle Shirtwaist fire, the actions necessary to bring an end to this long season of horror, and the initial steps taken in this direction since the Rana Plaza collapse.

\section{How We Got Here}

Although apparel brands and retailers pay ample lip service to worker rights and worker safety, dangerous and degrading working conditions are a product of their own manufacturing strategies. Today's global apparel supply chains have the following salient features: (1) brands and retailers generally eschew ownership of manufacturing capacity and instead assign their production to contract factories; (2) relations with these producers are defined by short-term contracts for specific orders of apparel with no guarantee of continued business; (3) brands and retailers usually limit their production in a given factory to a modest portion of the factory's overall output, so factory owners must piece together numerous short-term orders from a long list of current and prospective customers in order to survive; and (4) with barriers to entry into garment production low, and with large numbers of workers desperate for some form of employment, there is excess capacity on the production side, allowing brands and retailers to bargain prices, and order deadlines, downward by exploiting competition between suppliers. 
These factors combine to generate intense and consistent pressure on producers to cut costs, and therefore prices, by any means available; they understand that if they cannot meet a given customer's price demands, there is another factory, across the street or across the world, that will. The options for reducing production costs are limited; factory owners have virtually no ability to reduce the cost of cloth, or of power, or of sewing machines. The one cost over which they can exert substantial control is labor.

The barrier to achieving large savings by squeezing labor-underpaying relative to the minimum wage, forcing workers to endure long hours of overtime, cutting corners on workplace safety, firing workers who try to unionize-is that apparel exporting countries generally have strong labor laws. In many cases, laws concerning such issues as mandatory benefits, limits on overtime, protection for women workers, and occupational health and safety are as strong as, or stronger than, those in the United States. If factory owners had to follow these laws, they would have about as much control over the cost of labor as they do over the cost of cotton. Fortunately for them, and unfortunately for those who sew garments for a living, governments are every bit as attuned to the priorities of foreign buyers and investors as local factory owners are. Believing, with strong historical basis, that brands and retailers will reward those countries that keep labor costs to a minimum and punish those that fail to do so, governments in apparel exporting countries are notoriously willing to abdicate regulatory responsibility.

Garment factory operators therefore have both powerful incentive (relentless pressure on price and delivery speed) and ready means (lax regulation) to reduce production costs by running roughshod over the rights of workers. This is the dynamic that explains the contemporary sweatshop and is at the root of every major category of labor rights abuse in the garment sector, including the heedless safety practices that have advanced the macabre parade of fires and building collapses in Bangladesh and elsewhere.

The astounding growth of garment production in Bangladesh is a testament to the overriding importance of cost reduction to brands and retailers and their willingness to tolerate abusive and dangerous working conditions as a means to that end, despite their public insistence that worker rights rank high as a corporate priority. Bangladesh offers very few advantages to brands and retailers: productivity levels have never been high, transportation infrastructure is shambolic and has been slow to improve, political instability is a constant threat (Berg et al. 2011). Meanwhile, the country's record on labor rights is among the worst in the industry (Wood 2010; International Trade Union Confederation 2014; Human Rights Watch 2015a). Until the government came under significant pressure in 2013, there were no unions in Bangladesh, and in the face of continued resistance from factory management, less than 5 percent of workers 
are currently organized (Westervelt 2015). The "troublemakers" are fired, often threatened with police repression, and, increasingly, face violent retaliation (Ali Manik and Bajaj 2012).

How does a highly inefficient producer with a terrible human rights reputation become the second-largest garment exporter on the globe? It does so by offering labor costs lower, by a sizable margin, than any of its competitors-low enough to more than offset the inefficiency-and by betting that the unsavory means utilized to achieve those cost savings, and the ugly consequences for workers, will not deter brands and retailers from taking advantage.

The year before the Rana Plaza collapse, Bangladeshi garment factories exported garments worth more than $\$ 80$ billion at retail, enough production to give two-dozen pieces of clothing to every person in the United States. ${ }^{1}$ The factories employ more than 3.5 million workers in the process, over a million more than were employed in the US garment industry during its mid-twentiethcentury peak. Only China, the undisputed industrial behemoth of the early twenty-first century, has a larger garment sector than Bangladesh-and, with garment-worker wages in China now high by industry standards, at $\$ 1.25$ an hour, Bangladesh and other super-low-cost producers are taking over a growing chunk of China's business (BGMEA 2015).

\section{Relentless Price Pressure}

The relentless, and spectacularly successful, drive of apparel brands and retailers for lower production costs is reflected in the trend in the retail price of clothing. Between 1994 and 2014, the overall price of consumer goods in the United States increased by 87 percent; for apparel, prices declined by 6 percent (US Bureau of Labor Statistics 2015). This means that, after inflation, the price American consumers pay for clothing has dropped 50 percent over the last two decades.

Given the effect of low-cost imports on wages in the North, it is debatable whether saving a few hundred dollars a year in clothing costs represents a genuine benefit to Northern consumers; what is beyond dispute is that garment workers in the Global South pay for these savings in the form of depressed income and substandard conditions of work.

A recent study by the Center for American Progress and the Worker Rights Consortium found that the real wages of apparel workers in the large majority of top apparel-producing countries decreased substantially between 2001 and 2011; the study shows that the prevailing wage for garment workers in all of the countries was found to be a small fraction of a conservatively defined living wage (Center for American Progress et al. 2013). In Bangladesh, the minimum wage for garments workers is 32 cents an hour-after a 77 percent increase in 


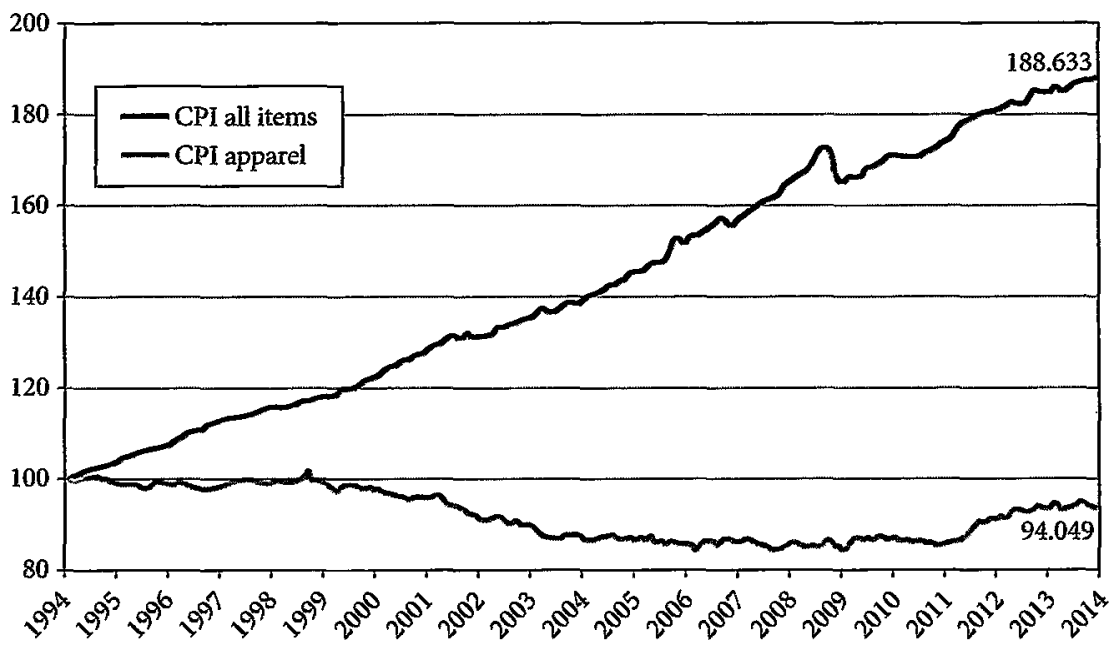

FIGURE 1.1 The falling prices of apparel relative to all consumer goods Source: US Bureau of Labor Statistics 2015

2013 , implemented in the face of mass worker protests and growing international pressure on the Bangladesh government driven by revulsion over the Rana Plaza collapse. This 32 cents an hour is less than it costs a garment worker to shelter, clothe, and feed herself, much less her dependents.

\section{Failure of Corporate Self-Regulation}

Low wages, abusive conditions, and disregard for workplace safety keep production costs low, but they also create risks for brands and retailers, as the Tazreen fire and the Rana collapse demonstrate. For apparel corporations, brand image and reputation are highly valued assets; devaluation of these assets, through association with sweatshop conditions, can yield lasting damage.

Faced with stinging criticism over conditions in their overseas factories, and forced to acknowledge that governments in the countries where they are producing do not regulate factories effectively, apparel corporations, beginning in the 1990s, publicly accepted responsibility for policing labor practices in their supply chains. ${ }^{2}$ Today, every major apparel brand and retailer has a labor rights "code of conduct" and a factory monitoring program, involving a pledge to regularly inspect their supplier factories using either in-house personnel or contract auditors, to press factories to correct any labor rights or safety violations identified, and to stop doing business with factories that refuse to comply. 
This is not regulation, it is self-regulation. These are voluntary programs; brands and retailers promise to ensure respect for worker rights and worker safety in their supply chains, but they make no binding commitments to any third party. Whether apparel corporations follow through on their pledges is at their sole discretion. The monitoring process is controlled and run by the brands and retailers; the inspectors work for them. The brands and retailers tell the inspectors what to look for, exclude those issues they choose to exclude, and act-or don't act-on the inspectors' findings as they see fit. Public pressure to live up to their official labor rights promises can, in some circumstances, be brought to bear on brands and retailers, but the brands and retailers sharply limit transparency in order to minimize the ability of advocates to do so: inspection results are kept secret (from workers as well as from the public) and the only information that gets reported is what the brands and retailers choose to report (generally, glossy paeans to the great progress ostensibly being achieved, backed up by little to no hard information).

The official goal of these programs is in conflict with the brands' and retailers' short-term economic interests: it costs more to produce under good conditions than bad conditions. Factories that observe the minimum wage, pay required overtime premiums, refrain from forcing workers to stay overnight when orders are due, provide maternity leave where the law requires it, and invest in necessary safety equipment will have higher production costs than factories that ignore these requirements, and will therefore need higher prices. Thus if brands are successful in compelling their factories to come into compliance with the applicable local law and the brands' own labor standards, the brands' costs will increase and profits will be reduced accordingly. The cost impact of genuine compliance is modest, but significant, and cost sensitivity is deeply ingrained in the culture of the industry. Thus if brands and retailers faithfully carry out their labor rights pledges, they will produce a result that they otherwise strive relentlessly to avoid.

Given these realities, is not surprising that these programs have failed to achieve high levels of labor rights and worker safety compliance in global apparel supply chains. When the goal of achieving the lowest production costs comes into conflict with corporations' labor rights promises-as it does on a daily basis-there is nothing to stop companies from subordinating fundamental human rights concerns to immediate financial exigencies. Factory monitoring programs are honor systems operating in a cut-throat business, with predictable results.

The failure of the self-regulatory approach has been brought into starkest relief by recent factory disasters. Every one of the apparel factories where dozens or hundreds of workers have died in the last several years had been repeatedly inspected under the brands' and retailers' monitoring regimes. The 
conflagration in September 2012 at the Ali Enterprises factory (in Karachi, Pakistan) was the worst factory fire in world history, with a death toll of more than 250 . Incredibly, the factory had been certified as a safe and responsible workplace just three weeks before the fire, under Social Accountability International's factory inspection program (Walsh and Greenhouse 2012a; Walsh and Greenhouse 2012b). It was also earlier inspected by UL Responsible Sourcing, an auditing firm contracted by the German retailer Kik (CCC and SOMO 2013). The various factories in the Rana Plaza building that collapsed in April 2013 all produced for brands and retailers with factory monitoring programs, including Loblaw (owner of Joe Fresh) and Children's Place (CCC 2015). Two of the factories had undergone, and passed, inspections carried out by the industry-run Business Social Compliance Initiative (BSCI 2013). The Garib \& Garib factory in Dhaka, which burned in February 2010, killing 22 people, had been audited repeatedly by H\&M, a leading member of the Fair Labor Association (Hickman 2010). That's It Sportswear, another factory in Dhaka where 29 workers died in a fire in December 2010, had been monitored by all of the major brands that produced there. These include Gap, a board member of SAI and a leading participant in the Global Social Compliance Program; VF Corporation, owner of Timberland, Nautica, and other brands and a key player in Worldwide Responsible Accredited Production; and PVH Corp., one of the founders of the FLA (VF Corporation 2011; Maquila Solidarity Network 2012a). The fire at Tazreen Fashions, where at least 112 workers died in November 2012, came after years of labor audits by Walmart (the founder of the Global Social Compliance Program) and other "socially responsible" brands and retailers. Tazreen, like all of these factories, had grave safety deficiencies (Henn 2013). Yet none of the audits by Walmart or the other buyers yielded any corrective action or gave a single word of warning to the workers.

All of these factories were covered by one or more of the multistakeholder monitoring organizations. All were producing for brands and retailers that claim to be operating robust factory inspection programs. All of these tragedies were preventable. Aside from empty promises routinely issued in the wake of each disaster, the brands and retailers did not deviate from their course: continued increases in production in countries with unsafe factories and continued use of obviously inadequate inspection regimes as the only means to address worker rights and worker safety.

What is perhaps most shocking is that even after similar disasters were repeated again and again, inspectors were not even asked to look for hazards that were killing workers. The two biggest factors in the mass deaths of apparel workers-absence of properly constructed fire exits and flaws in building construction-have not even been part of the audit checklists that are used by 
industry monitors. For example, it is likely that none of the apparel factories in Bangladesh had proper fire exits, yet factory managers have credibly reported that this extremely hazardous form of noncompliance has never been raised in the audits that retailers have conducted in their factories (Alam 2012).

The auditing firm employees and brand personnel who conduct factory inspections do not have adequate training in fire and building safety to conduct competent assessments, a fact brands themselves have acknowledged (Greenhouse and Yardley 2012; Clifford and Greenhouse 2013). Visits to factories are too brief for inspectors to sufficiently evaluate all of the issues they claim to investigate. Even when violations are found, they have no power to address the root causes of problems; voluntary monitoring carries no influence over production, order contracts, or funding of repairs.

These programs have been in place in all major apparel producing countries for more than a decade (AFL-CIO 2013). Most factories are inspected several times a year. Despite its ineffectiveness, not only has this system remained fundamentally unchanged but its use has also proliferated. The programs are clearly not designed as a tool to protect workers, but rather serve as an alibi for brands. The problem is not technical, it is economic and political; in a price-driven, hypercompetitive, high-pressure industry like apparel, self-policing doesn't work. The result is perpetuation of a status quo where exploited workers are killed en masse with appalling regularity.

\section{Bangladesh: The World's Sweatshop}

The modern epicenter of industrial horror in today's global economy is Bangladesh. Since 2005, nearly 2,000 people have died in factory fires and building collapses in Bangladesh. Wages are the lowest anywhere in the industry: a prevailing wage of 31 cents an hour (up from 18 cents an hour last year as a result of international pressure and domestic worker organizing). The cost of living is comparatively high; the World Bank pegs the cost of living at more than one fifth that of the United States. Key protections in labor law, from pregnancy leave to limits on overtime hours, are routinely ignored. Verbal abuse of workers is standard operating procedure, and physical and sexual abuse is not uncommon. Any attempt by workers to address these issues by advocating for better conditions and wages is met with swift and harsh repression. Until the government came under significant pressure in 2013, there were no unions in Bangladesh, and in the face of continued resistance from factory management, less than 3 percent of workers are currently organized. The "trouble-makers" are fired, often threatened with police repression and, increasingly, face violent retaliation. If there is a race to the bottom, Bangladesh has won it. 